\title{
Stereoselective addition of organotin anions to R-(+)-pulegone: a route to 8-triorganostannylmenthols
}

\author{
Verónica I. Dodero, ${ }^{\text {abb }}$ Nelda N. Giagante, ${ }^{a}$ Sandra D. Mandolesi, ${ }^{\text {a }}$ \\ Adriana E. Zúñiga, ${ }^{\mathrm{a}}$ and Julio C. Podestá ${ }^{\mathrm{a}, \mathrm{b}_{*}}$ \\ ${ }^{a}$ Instituto de Investigaciones en Quimica Organica, Departamento de Quimica, Universidad \\ Nacional del Sur, Avda. Alem 1253, 8000 Bahia Blanca, Argentina. ${ }^{b}$ Consejo Nacional de \\ Investigaciones Cientificas y Tecnicas (CONICET), Buenos Aires, Argentina \\ E-mail: jpodesta@uns.edu.ar
}

\section{Dedicated to Professor Edmundo A. Rúveda on his $70^{\text {th }}$ birthday and to Professor Roberto A. Rossi on his $60^{\text {th }}$ birthday}

(received 29 Aug 03; accepted 27 Sep 03; published on the web 02 Oct 03)

\begin{abstract}
A study on the addition of trimethyl-, tri-n-butyl-, triphenyl-, and (-)-menthyldimethyltin lithium to $(\mathrm{R})-(+)$-pulegone (5) and (E)-benzalcyclohexanone (8) is reported. It was found that the conjugate addition of the organotin anions to 5 lead in the four cases to mixtures of two adducts in good yields (70-80\%) and satisfactory diastereomeric excesses, d.e. (60-78\%). The additions to 6 took place mostly in satisfactory yields (64-66\%), but in very low yield in the case of the addition of (-)menthyldimethyltin lithium (23\%); the d.e. were in the range of 36 to $100 \%$. The addition of phenyl lithium in toluene to some of the new stannyl ketones led to the corresponding tertiary alcohols in fair yields (42-63\%), and with d.e. of 40-100\%. The reduction of some of the stannyl ketones with borane in THF catalyzed by a Corey catalyst gave the corresponding alcohols in ca $60 \%$ yield and with d.e. of $65 \%$. Full ${ }^{1} \mathrm{H}-,{ }^{13} \mathrm{C}-$, and ${ }^{119} \mathrm{Sn}-\mathrm{NMR}$ data of the new organotins are given.
\end{abstract}

Keywords: Stereoselective additions, organotin anions, phenyl lithium, stereoselective reductions, $(\mathrm{R})-(+)$-pulegone, $(\mathrm{E})$-benzalcyclohexanone

\section{Introduction}

The addition of organotin anions, i.e., compounds with tin-metal bonds to carbonyl compounds is a useful reaction for making carbon-tin bonds. ${ }^{1}$ The main studies on the 1,4-additions of organotin anions to $\alpha, \beta$-unsaturated acyclic carbonyl systems and their stereochemistry were carried out during the 1980 's. ${ }^{2,3}$ As part of our current interest on the synthesis and chemical 
properties of functionally substituted organotin compounds, we also reported the results obtained in the study of the stereochemistry of the addition of trineophyltinlithium to open chain enones. ${ }^{4 a}$ In this paper we report the results obtained in a study on the addition of triorganotinlithium compounds to (R)-(+)-pulegone (5) and (E)-benzalcyclohexanone (8), and also reactions of some of the new triorganostannyl ketones. It should be noted that part of the results obtained in these studies has been reported in a recent Symposium. ${ }^{4 b}$

\section{Results and Discussion}

First we carried out the addition of trimethyl- (1), tri-n-butyl- (2), triphenyl- (3), and (-)menthyldimethyltinlithium (4) to (R)-(+)-pulegone (5), according to Scheme 1.

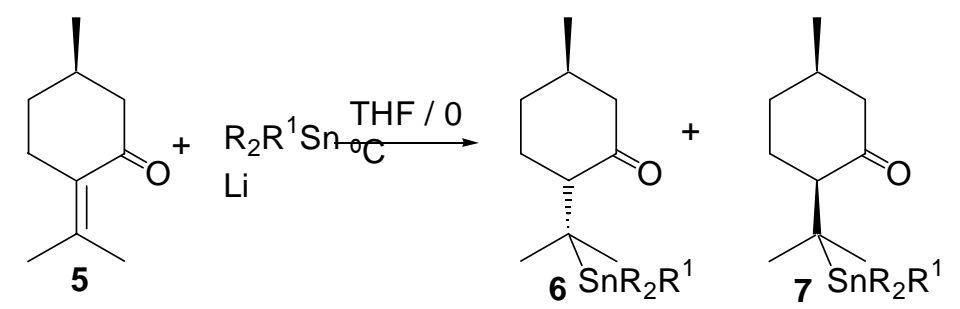

\begin{tabular}{rccc}
\hline & $\begin{array}{c}6+7 \\
(\%)\end{array}$ & $\begin{array}{c}6 \\
(\%)\end{array}$ & $\begin{array}{c}7 \\
(\%)\end{array}$ \\
\hline $\mathrm{a}: \mathrm{R}=\mathrm{R} 1=\mathrm{Me}$ & 74 & 80 & 20 \\
$\mathrm{~b}: \mathrm{R}=\mathrm{R} 1=\mathrm{Bu}$ & 70 & 89 & 11 \\
$\mathrm{c}: \mathrm{R}=\mathrm{R} 1=\mathrm{Ph}$ & 80 & 85 & 15 \\
$\mathrm{~d}: \mathrm{R}=\mathrm{Me} ; \mathrm{R} 1=(-)-M e n t h y 1$ & 70 & 84 & 16 \\
\hline
\end{tabular}

\section{Scheme 1}

The analysis of the crude products of these additions by ${ }^{119} \mathrm{Sn}-\mathrm{NMR}$, showed that in all cases they consisted of mixtures of two adducts (Scheme 1, compounds 6 and 7). As shown in Scheme 1 , the yields were good (70-80\%) and the diastereoisomeric excesses (d.e.) were in the range 60$78 \%$. ${ }^{13} \mathrm{C}$ - and ${ }^{119} \mathrm{Sn}-\mathrm{NMR}$ spectroscopic characteristics of compounds 6 and 7 are summarized in Table 1. The ${ }^{13} \mathrm{C}$-NMR chemical shifts (Table 1) were assigned through the analysis of the multiplicity of the signals by means of DEPT experiments and taking into account the magnitude of ${ }^{\mathrm{n}} \mathrm{J}\left({ }^{13} \mathrm{C},{ }^{119} \mathrm{Sn}\right)$ coupling constants.

The use of the Karplus-type relationship existing between the value of the ${ }^{3} \mathrm{~J}(\mathrm{C}, \mathrm{Sn})$ coupling constants and the dihedral angle, ${ }^{5}$ enabled us to deduce the stereochemistry of these compounds. Thus, the ${ }^{3} \mathrm{~J}(\mathrm{C}, \mathrm{Sn})$ values ranging from 20.5 to $32.1 \mathrm{~Hz}$ for carbon $\mathrm{C}-3$ of the ring observed for compounds 6a-6d (diastereoisomers 2R,5R in higher proportion), correspond to dihedral angles close to $60^{\circ}$ between these carbons and the tin moiety attached to C-8 (see Figure 1). Similarly, the values of ${ }^{3} \mathrm{~J}(\mathrm{C}, \mathrm{Sn})$ couplings constants for isomers $7 \mathbf{a}$ and $7 \mathrm{c}$ within the range $66.3-78.6 \mathrm{~Hz}$ Table 1, C-3) indicate an angle of about $180^{\circ}$ between the trialkylstannyl substituent and C-3 
(diastereoisomers $2 \mathrm{~S}, 5 \mathrm{R}$ ). These results are in agreement with those obtained by making and optimizing the corresponding models that lead to structures with dihedral angles of around $74^{\circ}$ for compounds of type 6 and of $176^{\circ}$ for type 7 compounds, as shown in Figure 1.

Table 1. ${ }^{13} \mathrm{C}$ and ${ }^{119} \mathrm{Sn}$ Data of (R)-(+)-pulegone (5) adducts 6a-d and 7a-d ${ }^{\text {a }}$

\begin{tabular}{|c|c|c|c|c|c|c|c|c|}
\hline $\mathrm{N}^{\circ}$ & $\mathrm{R}$ & $\mathrm{R}^{1}$ & $\begin{array}{c}\mathrm{C}(1) \\
{\left[{ }^{3} \mathrm{~J}(\mathrm{Sn}, \mathrm{C})\right]}\end{array}$ & $\begin{array}{c}\mathrm{C}(2) \\
{\left[{ }^{2} \mathrm{~J}(\mathrm{Sn}, \mathrm{C})\right]}\end{array}$ & $\begin{array}{c}\mathrm{C}(3) \\
{\left[{ }^{3} \mathrm{~J}(\mathrm{Sn}, \mathrm{C})\right]}\end{array}$ & $\begin{array}{c}\mathrm{C}(8) \\
{\left[{ }^{1} \mathrm{~J}(\mathrm{Sn}, \mathrm{C})\right]}\end{array}$ & $\mathrm{b}$ & ${ }^{119} \mathrm{Sn}$ \\
\hline $6 a$ & $\mathrm{Me}$ & $\mathrm{Me}$ & $\begin{array}{c}212.70 \\
(14.6)\end{array}$ & $\begin{array}{c}60.50 \\
(7.8)\end{array}$ & $\begin{array}{l}28.86 \\
(20.5)\end{array}$ & $\begin{array}{c}24.60 \\
(434.6)\end{array}$ & $\mathrm{c}$ & 12.7 \\
\hline $7 a$ & $\mathrm{Me}$ & $\mathrm{Me}$ & $\begin{array}{c}214.60 \\
(14.7)\end{array}$ & $\begin{array}{l}61.90 \\
(7.3)\end{array}$ & $\begin{array}{l}28.42 \\
(78.6)\end{array}$ & $\begin{array}{c}24.70 \\
(435.0)\end{array}$ & $\mathrm{d}$ & 14.0 \\
\hline $6 b$ & $\mathrm{Bu}$ & $\mathrm{Bu}$ & $\begin{array}{c}213.20 \\
(16.1)\end{array}$ & $\begin{array}{c}61.40 \\
(6.8)\end{array}$ & $\begin{array}{l}27.92 \\
(31.3)\end{array}$ & $\begin{array}{c}26.50 \\
(388.9)\end{array}$ & $\mathrm{e}$ & -8.26 \\
\hline $7 \mathbf{b}$ & $\mathrm{Bu}$ & $\mathrm{Bu}$ & $\begin{array}{c}212.90 \\
(16.6)\end{array}$ & $\begin{array}{c}61.00 \\
(6.6)\end{array}$ & $b$ & $\begin{array}{c}26.10 \\
(388.9)\end{array}$ & $\mathrm{f}$ & -6.9 \\
\hline $6 c$ & $\mathrm{Ph}$ & $\mathrm{Ph}$ & $\begin{array}{c}214.10 \\
(21.4)\end{array}$ & $\begin{array}{c}60.70 \\
(8.9)\end{array}$ & $\begin{array}{l}26.65 \\
(32.1)\end{array}$ & $\begin{array}{c}30.40 \\
(502.5)\end{array}$ & $\mathrm{g}$ & -115.4 \\
\hline 7c & $\mathrm{Ph}$ & $\mathrm{Ph}$ & $\begin{array}{c}214.80 \\
(21.5)\end{array}$ & $\begin{array}{c}61.70 \\
(8.9)\end{array}$ & $\begin{array}{l}27.08 \\
(66.3)\end{array}$ & $\begin{array}{c}30.30 \\
(501.7)\end{array}$ & $\mathrm{h}$ & -116.6 \\
\hline $6 d$ & $\mathrm{Me}$ & (-)Men & $\begin{array}{c}213.70 \\
(14.1)\end{array}$ & $\begin{array}{c}61.20 \\
(7.1)\end{array}$ & $\begin{array}{l}28.93 \\
(21.1)\end{array}$ & $\begin{array}{c}25.10 \\
(434.3)\end{array}$ & $\mathrm{i}$ & 14.5 \\
\hline $7 d$ & $\mathrm{Me}$ & (-)Men & $\begin{array}{c}214.50 \\
(14.7)\end{array}$ & $\begin{array}{c}62.30 \\
(7.0)\end{array}$ & $\begin{array}{l}27.16 \\
(\mathrm{NO})\end{array}$ & $\begin{array}{c}24.70 \\
(434.1)\end{array}$ & $\mathrm{j}$ & 15.8 \\
\hline
\end{tabular}

${ }^{\mathrm{a}}$ In $\mathrm{CDCl}_{3}$; chemical shifts, $\delta$, in ppm with respect to TMS $\left({ }^{13} \mathrm{C}\right.$ spectra $)$ and $\mathrm{Me}_{4} \mathrm{Sn}\left({ }^{119} \mathrm{Sn}\right.$ spectra); ${ }^{\mathrm{n}} \mathrm{J}(\mathrm{Sn}, \mathrm{C})$ coupling constants, in $\mathrm{Hz}$ (in brackets); $\mathrm{NO}=$ not observed. ${ }^{\mathrm{b}}$ Signals superimposed. ${ }^{\mathrm{b}}$ Other signals: ${ }^{\mathrm{c}}$-8.6 (311.1); 22.26; 24.59 (9.0 Hz); 28.09; 28.17 (NO); 34.17; 50.82. ${ }^{\mathrm{d}}-8.70(310.4) ; 22.77 ; 24.52$ (9.7); $27.92(9.6) ; 34.17 ; 35.80 ; 50.61{ }^{\mathrm{e}} 8.80$ (302.3); 9.50; $14.58 ; 16.51$ (8.2); 18.07 (31.4); 20.5; 22.44; 23.35; $34.35(\mathrm{NO}) ; 35.78 ; 50.93$ (NO). ${ }^{\mathrm{f}} 10.52$ (302.4); 23.05; 24.05 (10.7); 28.18 (NO); 31.73; 32.25; 49.50 (NO). ${ }^{\mathrm{g}} 22.12 ; 25.03$ (8.1); 29.08 (8.9); $33.86(\mathrm{NO}) ; 35.04 ; 50.10(\mathrm{NO}) ; 142.00$ (457.7). ${ }^{\mathrm{h}} 22.99 ; 25.04(7.2) ; 29.26(8.9) ; 33.86$ (NO); 35.07; 50.10 (NO); 142.10 (457.8); ${ }^{\mathrm{i}}-8.10$ (311.0); 23.94; 27.17; 30.26; 33.64; 35.03; $40.65 ; 49.96 .^{\mathrm{j}}-8.20(311.8) ; 23.6 ; 27.23 ; 30.26 ; 34.71 ; 35.10 ; 39.49 ; 47.94$. 

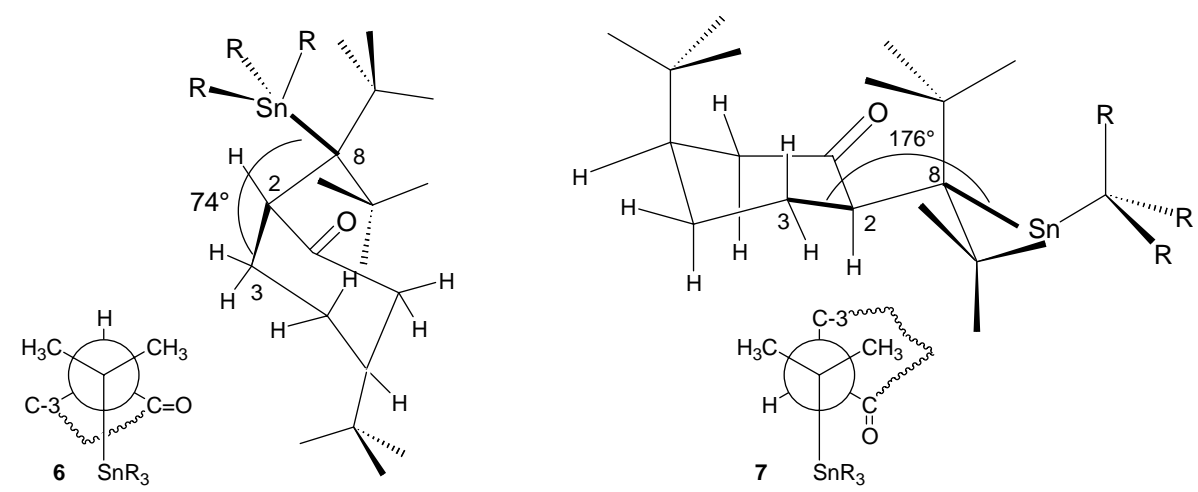

\section{Figure 1}

It should be mentioned that compounds 6a and 7a have also been obtained from $(+)$-pulegone through a two steps process as a mixture, in a ratio 3 to 1 (total yield $76 \%$ ). ${ }^{6}$

The addition of trimethyl- (1) and (-)-menthyldimethyltinlithium (4) to (E)benzalcyclohexanone (8) lead to mixtures of the four expected stereoisomers in both cases, whereas the addition of triphenyltinlithium (3) gives only a mixture of the stereoisomers $2 \mathrm{~S}, 7 \mathrm{R}$ and 2R,7S, as shown in Scheme 2. All attempts made in order to add tri-n-butyltinlithium (2) to 8 failed, these reactions leading in all cases to mixtures of hexabutylditin and starting ketone.

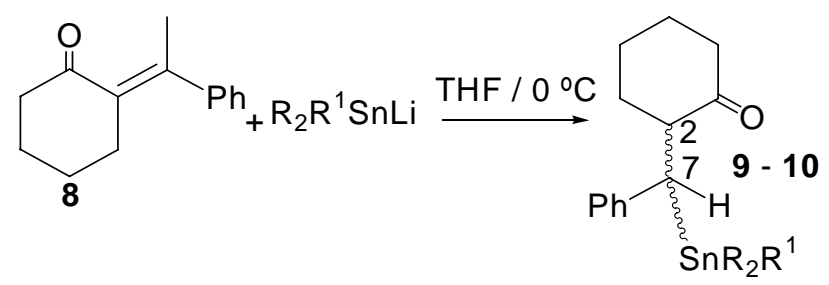

\begin{tabular}{rccc}
\hline & $9+10$ & $9(2 \mathrm{~S}, 7 \mathrm{R}+2 \mathrm{R}, 7 \mathrm{~S})$ & $10(2 \mathrm{~S}, 7 \mathrm{~S}+2 \mathrm{R}, 7 \mathrm{R})$ \\
& $(\%)$ & $(\%)$ & $(\%)$ \\
$\mathrm{a}: \mathrm{R}=\mathrm{R} 1=\mathrm{Me}$ & 60 & 80 & 20 \\
$\mathrm{~b}: \mathrm{R}=\mathrm{R} 1=\mathrm{Ph}$ & 64 & 100 & -- \\
$\mathrm{c}: \mathrm{R}=\mathrm{Me} ; \mathrm{R} 1=(-)-$ Menthyl & 23 & 68 & 32 \\
\hline
\end{tabular}

\section{Scheme 2}

As shown in Scheme 2, the additions of trimethyl (1) and triphenyltinlithium (3) give the corresponding adducts in good yields (ca. 62\%) and d.e. of 60 and $100 \%$ respectively. We were not able to improve the yield of the addition of 4 to $8(23 \%)$, and the d.e. obtained, $36 \%$, was also lower than those obtained in the additions of tin anions $\mathbf{1}$ and $\mathbf{3}$. We could not separate neither the mixtures of stereoisomers $\mathbf{9}(2 \mathrm{~S}, 7 \mathrm{R}+2 \mathrm{R}, 7 \mathrm{~S})$ nor $\mathbf{1 0}(2 \mathrm{~S}, 7 \mathrm{~S}+2 \mathrm{R}, 7 \mathrm{R})$. 
Table 2. ${ }^{13} \mathrm{C}$ and ${ }^{119} \mathrm{Sn}$ Data of (E)-benzalcyclohexanone (8) adducts 9a-c, 10a, and 10c ${ }^{\text {a }}$

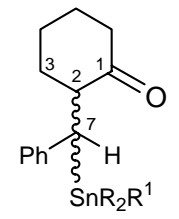

\begin{tabular}{|c|c|c|c|c|c|c|c|c|}
\hline $\mathrm{N}^{\circ}$ & $\mathrm{R}$ & $\mathrm{R}^{1}$ & $\begin{array}{c}\mathrm{C}(1) \\
{\left[{ }^{3} \mathrm{~J}(\mathrm{Sn}, \mathrm{C})\right]}\end{array}$ & $\begin{array}{c}\mathrm{C}(2) \\
{\left[{ }^{2} \mathrm{~J}(\mathrm{Sn}, \mathrm{C})\right]}\end{array}$ & $\begin{array}{c}\mathrm{C}(3) \\
{\left[{ }^{3} \mathrm{~J}(\mathrm{Sn}, \mathrm{C})\right]}\end{array}$ & $\begin{array}{c}\mathrm{C}(7) \\
{\left[{ }^{1} \mathrm{~J}(\mathrm{Sn}, \mathrm{C})\right]}\end{array}$ & $\mathrm{b}$ & ${ }^{119} \mathrm{Sn}$ \\
\hline $9 a$ & $\mathrm{Me}$ & $\mathrm{Me}$ & $\begin{array}{c}213.80 \\
(17.0)\end{array}$ & $\begin{array}{l}54,30 \\
(12.9)\end{array}$ & $\begin{array}{l}35.41 \\
(31.1)\end{array}$ & $\begin{array}{c}36.50 \\
(321.0)\end{array}$ & $\mathrm{c}$ & 7.2 \\
\hline $10 a$ & $\mathrm{Me}$ & $\mathrm{Me}$ & $\begin{array}{c}215.00 \\
(17.4)\end{array}$ & $\begin{array}{l}55,20 \\
(13.2)\end{array}$ & $\begin{array}{l}34.52 \\
(\mathrm{NO})\end{array}$ & $\begin{array}{c}36.90 \\
(321.3)\end{array}$ & d & 9.6 \\
\hline $9 b$ & $\mathrm{Ph}$ & $\mathrm{Ph}$ & $\begin{array}{l}212.70 \\
(32.2)\end{array}$ & $\begin{array}{l}52.80 \\
(15.2)\end{array}$ & $\begin{array}{l}32.21 \\
(39.6)\end{array}$ & $\begin{array}{c}38.70 \\
(391.4)\end{array}$ & $\mathrm{e}$ & -121.3 \\
\hline 9c & $\mathrm{Me}$ & (-)Men & $\begin{array}{c}213.50 \\
(13.5)\end{array}$ & $\begin{array}{l}53.80 \\
(12.9)\end{array}$ & $\begin{array}{l}34.52 \\
(36.9)\end{array}$ & $\begin{array}{c}34.50 \\
(334.2)\end{array}$ & $\mathrm{f}$ & 6.9 \\
\hline $10 c$ & $\mathrm{Me}$ & (-)Men & $\begin{array}{c}217.90 \\
(14.3)\end{array}$ & $\begin{array}{l}52.90 \\
(12.3)\end{array}$ & $\begin{array}{l}33.10 \\
(72.1)\end{array}$ & $\begin{array}{c}35.20 \\
(334.6)\end{array}$ & $\mathrm{g}$ & 9.4 \\
\hline
\end{tabular}

${ }^{\mathrm{a}}$ In $\mathrm{CDCl}_{3}$; chemical shifts, $\delta$, in ppm with respect to TMS $\left({ }^{13} \mathrm{C}\right.$ spectra $)$ and $\mathrm{Me}_{4} \mathrm{Sn}\left({ }^{119} \mathrm{Sn}\right.$ spectra); ${ }^{\mathrm{n}} \mathrm{J}(\mathrm{Sn}, \mathrm{C})$ coupling constants, in $\mathrm{Hz}$ (in brackets); $\mathrm{NO}=$ not observed. ${ }^{\mathrm{b}}$ Signals superimposed. ${ }^{\mathrm{b}}$ Other signals: ${ }^{\mathrm{c}}$-8.2 (326.8); 24.90; 27.99; 41.86; 144.93 (NO); 124.34 (12.9); 127.66 (23.5); 128.62 (10.6). ${ }^{\mathrm{d}}-7.80$ (327.0); 25.91; 28.89; 42.60; 124.12 (14.1); 126.95 (24.6); 128.82 (11.7); 146.90 (30.5). ${ }^{\mathrm{e}} 23.54 ; 25.61 ; 40.71 ; 123.49$ (14.1); 127.64; $136.29 ; 137.92$ (30.2); 139.27 (48.1); 141.20 (484.7). ${ }^{\mathrm{f}}-9.60$ (328.8); $24.51 ; 27.46 ; 41.17 ; 122.95$ (12.5); 126.29 (23.5); 127.22 (11.8); 144.69 (16.0). ${ }^{\mathrm{g}}-7.80$ (327.4); 22.47; 24.67; 41.63; 122.73 (11.1); 126.67 (23.3); $127.42(12.0) ; 143.54(15.6)$.

${ }^{13} \mathrm{C}$ - and ${ }^{119} \mathrm{Sn}-\mathrm{NMR}$ spectroscopic characteristics of the new compounds $\mathbf{9}$ and $\mathbf{1 0}$ are summarized in Table 2. The ${ }^{13} \mathrm{C}-\mathrm{NMR}$ chemical shifts (Table 1) were assigned as previously. Making use of the Karplus-type relationship mentioned above it is possible to establish the stereochemistry of these compounds. Thus, the ${ }^{3} \mathrm{~J}(\mathrm{C}, \mathrm{Sn})$ values ranging from 31.1 to $39.6 \mathrm{~Hz}$ for carbon $\mathrm{C}-3$ of the ring observed for compounds 9a-9c (mixtures of diastereomers with higher proportion $2 \mathrm{~S}, 7 \mathrm{R}+2 \mathrm{R}, 7 \mathrm{~S}$ ), indicate dihedral angles of about $60^{\circ}$ between these carbons and the tin moiety attached to C-7, i.e., gauche positions with respect to the triorganostannyl groups. The higher values found for the ${ }^{3} \mathrm{~J}(\mathrm{C}, \mathrm{Sn})$ couplings constants of C-3 in type $\mathbf{1 0}$ isomers, around $70^{\circ}$, support the existence of a dihedral angle of about $180^{\circ}$, i.e., an anti position with respect to the stannyl substituent (diastereoisomers $2 \mathrm{~S}, 5 \mathrm{R}+2 \mathrm{R}, 5 \mathrm{~S}$ ).

In order to obtain optically active stannyl alcohols needed for other studies, we first studied the addition of phenyllithium to the hindered stannylketones 6a-6c (Scheme 3). The reactions were carried out in a non-polar medium: the phenyllithium was prepared at $-78{ }^{\circ} \mathrm{C}$ in toluene and then added to a solution of the ketones in the same solvent at room temperature. ${ }^{6}$ 


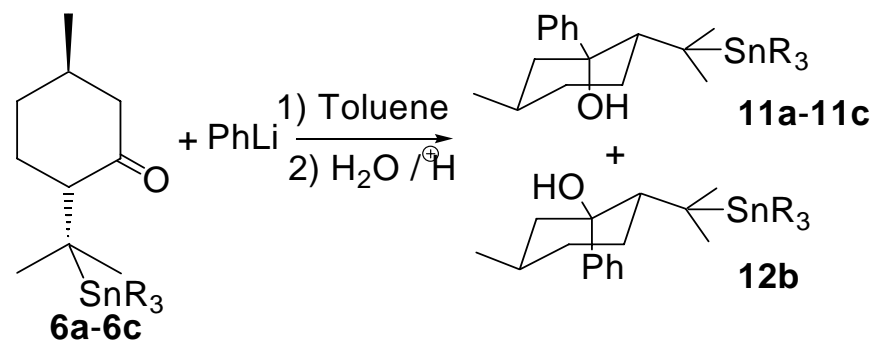

\begin{tabular}{lccc}
\hline & $\begin{array}{c}11+12 \\
(\%)\end{array}$ & $\begin{array}{c}11 \\
(\%)\end{array}$ & $\begin{array}{c}12 \\
(\%)\end{array}$ \\
\hline a: $\mathrm{R}=\mathrm{Me}$ & 77 & 100 & -- \\
b: $\mathrm{R}=\mathrm{Bu}$ & 78 & 85 & 15 \\
$\mathrm{c}: \mathrm{R}=\mathrm{Ph}$ & 68 & 100 & -- \\
\hline
\end{tabular}

\section{Scheme 3}

${ }^{13} \mathrm{C}$ - and ${ }^{119} \mathrm{Sn}-\mathrm{NMR}$ spectroscopic characteristics of the new compounds 11a-11c and 12b are summarized in Table 3.

Table $3 .{ }^{13} \mathrm{C}$ and ${ }^{119} \mathrm{Sn}$ Data of triorganostannyl alcohols 11a-c and $\mathbf{1 2} \mathbf{b}^{\text {a }}$

\begin{tabular}{|c|c|c|c|c|c|c|c|c|}
\hline $\mathrm{N}^{\circ}$ & $\mathrm{R}$ & $\mathrm{R}^{1}$ & $\begin{array}{c}\mathrm{C}(1) \\
{\left[{ }^{3} \mathrm{~J}(\mathrm{Sn}, \mathrm{C})\right]}\end{array}$ & $\begin{array}{c}\mathrm{C}(2) \\
{\left[{ }^{2} \mathrm{~J}(\mathrm{Sn}, \mathrm{C})\right]}\end{array}$ & $\begin{array}{c}\mathrm{C}(3) \\
{\left[{ }^{3} \mathrm{~J}(\mathrm{Sn}, \mathrm{C})\right]}\end{array}$ & $\begin{array}{c}\mathrm{C}(8) \\
{\left[{ }^{1} \mathrm{~J}(\mathrm{Sn}, \mathrm{C})\right]}\end{array}$ & $\mathrm{b}$ & ${ }^{119} \mathrm{Sn}$ \\
\hline 11a & $\mathrm{Me}$ & $\mathrm{Me}$ & $\begin{array}{l}77.95 \\
(17.4)\end{array}$ & $\begin{array}{l}61.53 \\
(7.0)\end{array}$ & $\begin{array}{l}29.02 \\
(20.5)\end{array}$ & $\begin{array}{c}31.95 \\
(471.7)\end{array}$ & $\mathrm{c}$ & 6.3 \\
\hline $11 b$ & $\mathrm{Bu}$ & $\mathrm{Bu}$ & $\begin{array}{l}77.91 \\
(23.5)\end{array}$ & $\begin{array}{r}60.51 \\
(7.0)\end{array}$ & $\begin{array}{l}26.84 \\
(56.3)\end{array}$ & $\begin{array}{c}32.73 \\
(331.1)\end{array}$ & $\mathrm{d}$ & -10.65 \\
\hline $12 b$ & $\mathrm{Bu}$ & $\mathrm{Bu}$ & $\begin{array}{l}77.12 \\
(27.0)\end{array}$ & $\begin{array}{r}60.73 \\
(7.0)\end{array}$ & $\begin{array}{l}26.89 \\
(57.4)\end{array}$ & $\begin{array}{l}33.47 \\
(\mathrm{NO})\end{array}$ & $\mathrm{e}$ & -9.3 \\
\hline 11c & $\mathrm{Ph}$ & $\mathrm{Ph}$ & $\begin{array}{l}75.53 \\
(15.2)\end{array}$ & $\begin{array}{r}59.76 \\
(8.2)\end{array}$ & $\begin{array}{l}25.63 \\
(33.0)\end{array}$ & $\begin{array}{c}29.5 \\
(500.2)\end{array}$ & $\mathrm{f}$ & -126.7 \\
\hline
\end{tabular}

${ }^{a}$ In $\mathrm{CDCl}_{3}$; chemical shifts, $\delta$, in ppm with respect to TMS $\left({ }^{13} \mathrm{C}\right.$ spectra) and $\mathrm{Me}_{4} \mathrm{Sn}\left({ }^{119} \mathrm{Sn}\right.$ spectra); ${ }^{\mathrm{n}} \mathrm{J}(\mathrm{Sn}, \mathrm{C})$ coupling constants, in $\mathrm{Hz}$ (in brackets); $\mathrm{NO}=$ not observed. ${ }^{\mathrm{b}}$ Signals superimposed. ${ }^{\mathrm{b}}$ Other signals: ${ }^{\mathrm{c}}-8.6(311.1) ; 22.26 ; 24.59$ (9.0 Hz); 28.09; 28.17 (NO); 34.17; 50.82. ${ }^{\mathrm{d}} 9.17$ (302.8); 7.88; $13.47(15.0) ; 15.83 ; 22.49 ; 23.46 ; 25.94 ; 33.70 ; 35.9548 .39(\mathrm{NO}) .{ }^{\mathrm{e}}$ $8.98(302.7) ; 8.87 ; 14.63 ; 16.12 ; 22.56 ; 23.58 ; 26.05 ; 33.40 ; 36.25 ; 49.02(\mathrm{NO}) .{ }^{\mathrm{f}} 21.12(45.8)$; 24.06; 25.63 (31.7); 28.11; 29.49 (8.8); 34.15 (NO); 38.72; 49.19; 136.70; 140.91 (457.2). 
The new quiral stannyl alcohols were obtained in good yields: $68-78 \%$, i.e., similar to those reported for the addition of phenyllithium to (-)-menthone and other hindered cyclic ketones. ${ }^{7}$ These reactions occur stereospecifically, leading in all cases to the alcohols resulting from the addition of the phenyl group to the less-hindered side of the carbonyl group (type 11 compounds). Our results confirm that the addition of phenyllithium to hindered ketones in nonpolar media can be achieved in good yields and with excellent selectivity. ${ }^{7}$

We then carried out the reduction of stannylketones 6a-6c with borane in THF in the presence of the Corey catalyst (S)-3,3-diphenyl-1-methyltetrahydro-3H-pyrrolo[1,2c][1,3,2] oxazaborole. These reductions took place with good yields leading in all cases to mixtures of the two possible alcohols with d.e. between 64 and 76\% (Scheme 4). Unfortunately, we could not separate these mixtures neither by vacuum distillation nor by column chromatography.

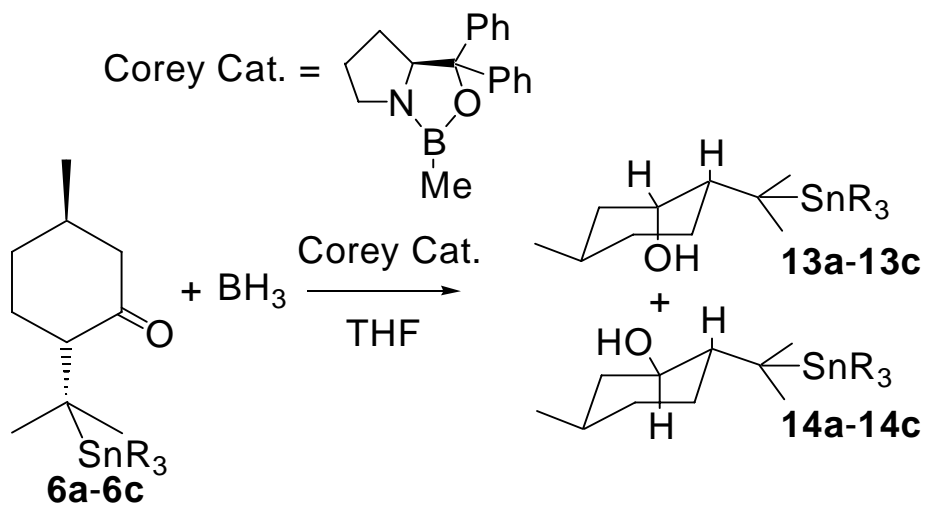

\begin{tabular}{cccc}
\hline & $13+14$ & 13 & 14 \\
& $(\%)$ & $(\%)$ & $(\%)$ \\
\hline a: $\mathrm{R}=\mathrm{Me}$ & 73 & 82 & 18 \\
b: $\mathrm{R}=\mathrm{Bu}$ & 78 & 87.5 & 12.5 \\
$\mathrm{c}: \mathrm{R}=\mathrm{Ph}$ & 50 & 88 & 12 \\
\hline
\end{tabular}

\section{Scheme 4}

In this case, we were able to deduce the stereochemistry around carbon C-1 by means of the ${ }^{1} \mathrm{H}-\mathrm{NMR}$ spectra of these compounds (see experimental). The ${ }^{3} \mathrm{~J}(\mathrm{H}, \mathrm{H})$ coupling constants of the protons attached to carbons $\mathrm{C}-1$ and $\mathrm{C}-2$ in the major diastereomers (13a-c) have values close to $4 \mathrm{~Hz}$ indicating a dihedral angle of around $60^{\circ}$ between these protons. This strongly suggests that in this case the configuration of $\mathrm{C}-1$ should be $\mathrm{S}$. On the other hand, the minor diastereoisomers 14a-c have ${ }^{3} \mathrm{~J}(\mathrm{H}, \mathrm{H})$ coupling constants between $6-10.5 \mathrm{~Hz}$ which are compatible with dihedral angles close to $180^{\circ}$ between these protons, indicating a possible R configuration of carbon 1 . 


\section{Conclusions}

Our results clearly demonstrate that the 1,4-addition of triorganostannyl lithium compounds to cyclic ketones with an exocyclic conjugated carbon-carbon double bond takes place with high stereoselectivity. The fact that the yields of these nucleophilic additions are lower when a substituent of large steric volume $(\mathrm{Ph})$ is attached to the last carbon of the conjugated system (additions to 8) suggests that the additions are affected by steric factors. In the case of the additions to (+)-pulegone each single optically active adduct is obtained pure. It is also demonstrated that the addition of phenyl lithium to the optically active menthones $\mathbf{6 a - 6 c}$ in toluene, leads in two cases with complete stereoselectivity, and in one case with $70 \%$ of d.e. to the corresponding adducts. Thus, the addition of organotin anions to (+)-pulegone followed by the addition of phenyl lithium to the resulting stannyl ketones, is an excellent method for the synthesis of optically active 1-phenyl-8-triorganostannylmenthols in good total yields (ca 56\%), and with complete or very high stereoselectivity.

On the other hand, we could not separate the mixtures of alcohols resulting from the reduction of stannyl ketones 6a-6c with borane in the presence of a Corey catalyst, and this limits de usefulness of this technique as a route for the synthesis of optically active 8triorganostannylmenthols.

\section{Experimental Section}

General Procedures. ${ }^{1} \mathrm{H}-,{ }^{13} \mathrm{C}$ - and ${ }^{119} \mathrm{Sn}$-NMR spectra were measured with a Bruker ARX 300. IR spectra were recorded with a FT-IR Nicolet Nexus 470/670/870 spectrophotometer. Microanalyses were performed at Dortmund University (Germany). Specific rotations were measured with a Polar L- $\mu$ P, IBZ Messtechnik instrument. All the solvents and reagents used were analytical reagent grade. (-)-Menthyldimethyltin chloride was obtained from (-)menthyltrimethyltin ${ }^{8}$ with known procedures. ${ }^{9}$ (E)-Benzalcyclohexanone ${ }^{10}$ and triorganotinlithium compounds were prepared according to literature methods. ${ }^{11}$

\section{Addition of triorganotinlithium to (+)-pulegone and (E)-benzalcyclohexanone}

All the reactions were carried out following the same procedure. ${ }^{12}$ One experiment is described in detail to illustrate the method used.

To a solution of trimethylstannyllithium in THF at $0{ }^{\circ} \mathrm{C}$, under nitrogen and magnetic stirring, was added dropwise a solution of (+)-pulegone $(1.37 \mathrm{~g}, 9 \mathrm{mmol})$ in dry THF $(7 \mathrm{ml})$. The mixture was allowed to reach room temperature and it was stirred overnight. Then a $10 \%$ solution of ammonium chloride was added and the crude product was extracted in ether, dried with sodium sulphate, and the solvent was eliminated under reducer pressure. The oily residue, $2.11 \mathrm{~g}(74 \%)$, was purified by column chromatography on silicagel 60 . Adduct 6a (1.6 g) was eluted with hexane /ether 97:3, while adduct 7a (0.5 g) was eluted with hexane/ether 95:5. 
(-)-8-Trimethylstannylmenthone (6a) ${ }^{6} .{ }^{1} \mathrm{H} \mathrm{NMR}\left(\mathrm{CDCl}_{3}\right) \delta-0.05\left(\mathrm{~s},{ }^{2} \mathrm{~J}(\mathrm{Sn}, \mathrm{H})=48.9 \mathrm{~Hz}, 9 \mathrm{H}\right)$, $0.96(\mathrm{~d}, 3 \mathrm{H}), 1.05\left(\mathrm{~s},{ }^{3} \mathrm{~J}(\mathrm{Sn}, \mathrm{H})=66.1 \mathrm{~Hz}, 6 \mathrm{H}\right), 1.25-1.37(\mathrm{~m}, 3 \mathrm{H}), 1.85-1.90(\mathrm{~m}, 4 \mathrm{H}), 1.96(\mathrm{t}$, $\left.{ }^{3} \mathrm{~J}(\mathrm{H}, \mathrm{H})=12.8 \mathrm{~Hz}, 1 \mathrm{H}\right),[\alpha]^{20}{ }_{\mathrm{D}}=-35.6^{\circ}\left(\mathrm{CHCl}_{3} ; 0.874\right)$.

(+)-8-Trimethylstannylmenthone (7a) ${ }^{6} .{ }^{1} \mathrm{H} \mathrm{NMR}\left(\mathrm{CDCl}_{3}\right) \delta-0.00\left(\mathrm{~s},{ }^{2} \mathrm{~J}(\mathrm{Sn}, \mathrm{H})=49.5 \mathrm{~Hz}, 9 \mathrm{H}\right)$, $0.91(\mathrm{~d}, 3 \mathrm{H}), 1.07\left(\mathrm{~s},{ }^{3} \mathrm{~J}(\mathrm{Sn}, \mathrm{H})=66.5 \mathrm{~Hz}, 6 \mathrm{H}\right), 1.52-1.73(\mathrm{~m}, 3 \mathrm{H}), 1.82-2.00(\mathrm{~m}, 4 \mathrm{H}), 2.13(\mathrm{t}$, $\left.{ }^{3} \mathrm{~J}(\mathrm{H}, \mathrm{H})=4.8 \mathrm{~Hz}, 1 \mathrm{H}\right),[\alpha]^{20}{ }_{\mathrm{D}}=+46.2^{\circ}\left(\mathrm{CHCl}_{3} ; 0.138\right)$.

(-)-8-Tributylstannylmenthone (6b). ${ }^{1} \mathrm{H}$ NMR $\left(\mathrm{CDCl}_{3}\right) \delta 1.00(\mathrm{~s}, 6 \mathrm{H}), 1.02(\mathrm{~d}, 3 \mathrm{H}), 1.10-1.34$ $(\mathrm{m}, 15 \mathrm{H}), 1.52-1.73(\mathrm{~m}, 9 \mathrm{H}), 1.78\left(\mathrm{t},{ }^{3} \mathrm{~J}(\mathrm{H}, \mathrm{H})=12.0 \mathrm{~Hz}, 1 \mathrm{H}\right), 1.82-1.96(\mathrm{~m}, 6 \mathrm{H}), 2.10-2.34(\mathrm{~m}$, 2H), 2.44-2.73 (m, 2H), $[\alpha]^{20}{ }_{\mathrm{D}}=-22.2^{\circ}\left(\mathrm{CHCl}_{3} ; 1.94\right)$. Anal. Calcd. for $\mathrm{C}_{22} \mathrm{H}_{44} \mathrm{OSn}: \mathrm{C}, 59.62 ; \mathrm{H}$, 10.01. Found: C, 59.68; H, 10.06.

(+)-8-Tributylstannylmenthone (7b). ${ }^{1} \mathrm{H}$ NMR $\left(\mathrm{CDCl}_{3}\right) \delta 1.03(\mathrm{~s}, 6 \mathrm{H}), 1.05(\mathrm{~d}, 3 \mathrm{H}), 1.15-1.36$ $(\mathrm{m}, 15 \mathrm{H}), 1.50-1.73(\mathrm{~m}, 9 \mathrm{H}), 1.83\left(\mathrm{t},{ }^{3} \mathrm{~J}(\mathrm{H}, \mathrm{H})=4.6 \mathrm{~Hz}, 1 \mathrm{H}\right), 1.90-1.96(\mathrm{~m}, 6 \mathrm{H}), 2.00-2.13(\mathrm{~m}$, 2H), 2.44-2.53 (m, 2H), $[\alpha]^{20}{ }_{D}=+40.3^{\circ}\left(\mathrm{CHCl}_{3} ; 0.721\right)$. Anal. Calcd. for $\mathrm{C}_{22} \mathrm{H}_{44} \mathrm{OSn}: \mathrm{C}, 59.62$; H, 10.01. Found: C, 59.71; H, 10.08.

(-)-8-Triphenylstannylmenthone (6c). ${ }^{1} \mathrm{H}$ NMR $\left(\mathrm{CDCl}_{3}\right) \delta 1.06(\mathrm{~d}, 3 \mathrm{H}), 1.57(\mathrm{~s}, 6 \mathrm{H}), 1.25-1.37$ $(\mathrm{m}, 3 \mathrm{H}), 1.85-1.90(\mathrm{~m}, 4 \mathrm{H}), 2.54\left(\mathrm{t},{ }^{3} \mathrm{~J}(\mathrm{H}, \mathrm{H})=12.5 \mathrm{~Hz}, 1 \mathrm{H}\right), 7.37-7.63(\mathrm{~m}, 9 \mathrm{H}), 7.76-7.95(\mathrm{~m}$, $6 \mathrm{H}),[\alpha]^{20}{ }_{\mathrm{D}}=-45.9^{\circ}\left(\mathrm{CHCl}_{3} ; 0.928\right)$. Anal. Calcd. for $\mathrm{C}_{28} \mathrm{H}_{32} \mathrm{OSn}$ : C, 66.84; H, 6.41. Found: C, $66.88 ; \mathrm{H}, 6.48$.

(+)-8-Triphenylstannylmenthone (7c). ${ }^{1} \mathrm{H}$ NMR $\left(\mathrm{CDCl}_{3}\right) \delta 1.00(\mathrm{~d}, 3 \mathrm{H}), 1.60(\mathrm{~s}, 6 \mathrm{H}), 1.28$ $1.32(\mathrm{~m}, 3 \mathrm{H}), 1.79-1.86(\mathrm{~m}, 4 \mathrm{H}), 2.30\left(\mathrm{t},{ }^{3} \mathrm{~J}(\mathrm{H}, \mathrm{H})=4.6 \mathrm{~Hz}, 1 \mathrm{H}\right), 7.08-7.43(\mathrm{~m}, 9 \mathrm{H}), 7.65-7.93$ $(\mathrm{m}, 6 \mathrm{H}),[\alpha]^{20}{ }_{\mathrm{D}}=+42.3^{\circ}\left(\mathrm{CHCl}_{3} ; 0.523\right)$. Anal. Calcd. for $\mathrm{C}_{28} \mathrm{H}_{42} \mathrm{OSn}: \mathrm{C}, 66.84 ; \mathrm{H}, 6.41$. Found: C, 66.80; H, 6.46 .

(-)-8-(-)-Menthyldimethylstannylmenthone (6d). ${ }^{1} \mathrm{H}$ NMR $\left(\mathrm{CDCl}_{3}\right) \delta-0.04\left(\mathrm{~s},{ }^{2} \mathrm{~J}(\mathrm{Sn}, \mathrm{H})=24.8\right.$ $\mathrm{Hz}, 6 \mathrm{H}), 0.84\left(\mathrm{~d},{ }^{3} \mathrm{~J}(\mathrm{Sn}, \mathrm{H})=52.3 \mathrm{~Hz}, 3 \mathrm{H}\right), 0.86(\mathrm{~d}, 1 \mathrm{H}), 1.00(\mathrm{~d}, 6 \mathrm{H}), 1.24-1.51$ (m, 5H), $1.60-$ $1.62(\mathrm{~m}, 1 \mathrm{H}), 1.85-1.94(\mathrm{~m}, 8 \mathrm{H}), 1.97(\mathrm{~d}, 3 \mathrm{H}), 2.01\left(\mathrm{t},{ }^{3} \mathrm{~J}(\mathrm{H}, \mathrm{H})=11.8 \mathrm{~Hz}, 1 \mathrm{H}\right), 2.11-2.36(\mathrm{~m}$, $6 \mathrm{H}), 2.6-2.8(\mathrm{~m}, 2 \mathrm{H}),[\alpha]^{20}{ }_{\mathrm{D}}=-45.65^{\circ}\left(\mathrm{CHCl}_{3} ; 2.46\right)$. Anal. Calcd. for $\mathrm{C}_{22} \mathrm{H}_{42} \mathrm{OSn}: \mathrm{C}, 59.90 ; \mathrm{H}$, 9.60. Found: C, 59.94; H, 9.64.

(+)-8-(-)-Menthyldimethylstannylmenthone (7d). ${ }^{1} \mathrm{H}$ NMR $\left(\mathrm{CDCl}_{3}\right) \delta 0.04\left(\mathrm{~s},{ }^{2} \mathrm{~J}(\mathrm{Sn}, \mathrm{H})=24.8\right.$ $\mathrm{Hz}, 6 \mathrm{H}), 0.86(\mathrm{~d}, 1 \mathrm{H}), 1.00(\mathrm{~d}, 6 \mathrm{H}), 1.04\left(\mathrm{~d},{ }^{3} \mathrm{~J}(\mathrm{Sn}, \mathrm{H})=52.6 \mathrm{~Hz}, 3 \mathrm{H}\right), 1.20-1.32$ (m, 5H), 1.60$1.62(\mathrm{~m}, 1 \mathrm{H}), 1.89-1.92(\mathrm{~m}, 8 \mathrm{H}), 1.97(\mathrm{~d}, 3 \mathrm{H}), 1.97\left(\mathrm{t},{ }^{3} \mathrm{~J}(\mathrm{H}, \mathrm{H})=2.8 \mathrm{~Hz}, 1 \mathrm{H}\right), 2.23-2.36(\mathrm{~m}$, $6 \mathrm{H}), 2.70-2.89(\mathrm{~m}, 2 \mathrm{H}),[\alpha]^{20}=+35.72^{\circ}\left(\mathrm{CHCl}_{3}\right.$; 5.3). Anal. Calcd. for $\mathrm{C}_{22} \mathrm{H}_{42} \mathrm{OSn}: \mathrm{C}, 59.90$; H, 9.60. Found: C, 59.96; H, 9.62.

(2S,7R + 2R,7S)-2-Phenyl(trimethylstannyl)methyl-1-cyclohexanone (9a). ${ }^{1} \mathrm{H} \mathrm{NMR}\left(\mathrm{CDCl}_{3}\right)$ $\delta 0.00\left(\mathrm{~s},{ }^{2} \mathrm{~J}(\mathrm{Sn}, \mathrm{H})=52.8 \mathrm{~Hz}, 9 \mathrm{H}\right), 2.11-2.45(\mathrm{~m}, 8 \mathrm{H}), 2.82\left(\mathrm{~d},{ }^{3} \mathrm{~J}(\mathrm{H}, \mathrm{H})=7.8 \mathrm{~Hz}\right) ;{ }^{2} \mathrm{~J}(\mathrm{Sn}, \mathrm{H})=$ $66.1 \mathrm{~Hz}, 1 \mathrm{H}), 3.01\left(\mathrm{~m},{ }^{3} \mathrm{~J}(\mathrm{H}, \mathrm{H})=7.8 \mathrm{~Hz}, 1 \mathrm{H}\right), 6.97-7.36(\mathrm{~m}, 5 \mathrm{H})$.

(2S,7S + 2R,7R)-2Phenyl(trimethylstannyl)methyl-1-cyclohexanone (10a). ${ }^{1} \mathrm{H} \mathrm{NMR}\left(\mathrm{CDCl}_{3}\right)$ $\delta 0.00\left(\mathrm{~s},{ }^{2} \mathrm{~J}(\mathrm{Sn}, \mathrm{H})=50.4 \mathrm{~Hz}, 9 \mathrm{H}\right), 0.97-2.57(\mathrm{~m}, 8 \mathrm{H}), 2.45\left(\mathrm{~d},{ }^{3} \mathrm{~J}(\mathrm{H}, \mathrm{H})=8.9 \mathrm{~Hz},{ }^{2} \mathrm{~J}(\mathrm{Sn}, \mathrm{H})=\right.$ $49.4 \mathrm{~Hz}, 1 \mathrm{H}), 3.1\left(\mathrm{~m},{ }^{3} \mathrm{~J}(\mathrm{H}, \mathrm{H})=8.9 \mathrm{~Hz}, 1 \mathrm{H}\right), 6.97-7.45(\mathrm{~m}, 5 \mathrm{H})$.

(2S,7R + 2R,7S)-2-Phenyl(triphenylstannyl)methyl-1-cyclohexanone (9b). ${ }^{1} \mathrm{H} \mathrm{NMR}\left(\mathrm{CDCl}_{3}\right)$, $\delta 2.9\left(\mathrm{~m},{ }^{3} \mathrm{~J}(\mathrm{H}, \mathrm{H})=7.2 \mathrm{~Hz}, 1 \mathrm{H}\right), 1.19-2.72(\mathrm{~m}, 8 \mathrm{H}), 3.44\left(\mathrm{~d},{ }^{3} \mathrm{~J}(\mathrm{H}, \mathrm{H})=7.2 \mathrm{~Hz},{ }^{2} \mathrm{~J}(\mathrm{Sn}, \mathrm{H})=\right.$ $79.5 \mathrm{~Hz}, 1 \mathrm{H}), 7.24-7.75(\mathrm{~m}, 20 \mathrm{H})$. 
(2S,7R + 2R,7S)-2-Phenyl[(-)menthyldimethylstannyl]methyl-1-cyclohexanone (9c). ${ }^{1} \mathrm{H}$ $\operatorname{NMR}\left(\mathrm{CDCl}_{3}\right) \delta-0.16\left(\mathrm{~s},{ }^{2} \mathrm{~J}(\mathrm{Sn}, \mathrm{H})=51.1 \mathrm{~Hz}, 6 \mathrm{H}\right), 0.0(\mathrm{~s}, 9 \mathrm{H}), 0.8-2.1(\mathrm{~m}, 15 \mathrm{H}), 2.27\left(\mathrm{~d},{ }^{3} \mathrm{~J}(\mathrm{H}\right.$, $\left.\mathrm{H})=8.9 \mathrm{~Hz},{ }^{2} \mathrm{~J}(\mathrm{Sn}, \mathrm{H})=47.5 \mathrm{~Hz}, 1 \mathrm{H}\right), 2.39\left(\mathrm{~m},{ }^{3} \mathrm{~J}(\mathrm{H}, \mathrm{H})=8.9 \mathrm{~Hz}, 1 \mathrm{H}\right), 6.8-7.18(\mathrm{~m}, 5 \mathrm{H})$.

(2S,7S + 2R,7R)-2-Phenyl[(-)menthyldimethylstannyl]methyl-1-cyclohexanone (10c). ${ }^{1} \mathrm{H}$ NMR $\left(\mathrm{CDCl}_{3}\right) \delta 0.00\left(\mathrm{~s},{ }^{2} \mathrm{~J}(\mathrm{Sn}, \mathrm{H})=49.9 \mathrm{~Hz}, 6 \mathrm{H}\right), 0.08(\mathrm{~s}, 9 \mathrm{H}), 0.6-2.4(\mathrm{~m}, 15 \mathrm{H}), 2.82\left(\mathrm{~d},{ }^{3} \mathrm{~J}(\mathrm{H}\right.$, $\left.\mathrm{H})=7.9 \mathrm{~Hz},{ }^{2} \mathrm{~J}(\mathrm{Sn}, \mathrm{H})=66.4 \mathrm{~Hz}, 1 \mathrm{H}\right), 2.98\left(\mathrm{~m},{ }^{3} \mathrm{~J}(\mathrm{H}, \mathrm{H})=7.9 \mathrm{~Hz}, 1 \mathrm{H}\right), 6.96-7.25(\mathrm{~m}, 5 \mathrm{H})$.

\section{Addition of phenyllithium to stannyl ketones 6a-6c}

All the reactions were carried out following the same procedure. ${ }^{7}$ One experiment is described in detail to illustrate the method used.

A stirred solution of $\mathrm{PhBr}(0.124 \mathrm{~g}, 0.79$ mmoles $)$ in $\mathrm{THF}\left(1.0 \mathrm{ml}\right.$.) at $-78{ }^{\circ} \mathrm{C}$ under argon was slowly treated with BuLi in hexane (1.42 M, $0.55 \mathrm{ml}$.). After $20 \mathrm{~min}$ the resulting mixture was added dropwise to a solution of (-)-8-Trimethylstannylmenthone $(\mathbf{6 a})(0.17 \mathrm{~g}, 0.53 \mathrm{mmol})$ in dry toluene $(1.3 \mathrm{ml}$.). The reaction was kept under the same conditions for $30 \mathrm{~min}$. and then it was allowed to reach room temperature. Then a $10 \%$ solution of ammonium chloride was added and the crude product was extracted in ether, dried with sodium sulphate, and the solvent was eliminated under reduced pressure, leading to $0.16 \mathrm{~g}(77 \%)$ of $(1 \mathrm{R}, 2 \mathrm{R}, 5 \mathrm{R})-(-)-5-$-methyl-2-(1methyl-1-trimethylstannylethyl)-1-phenyl-1-cyclohexanol (11a).

(1R,2R,5R)-(-)-5-Methyl-2-(1-methyl-1-trimethylstannylethyl)-1-phenyl-1-cyclohexanol (11a). ${ }^{1} \mathrm{H}$ NMR $\left(\mathrm{CDCl}_{3}\right) \delta 0.00\left(\mathrm{~s},{ }^{2} \mathrm{~J}(\mathrm{Sn}, \mathrm{H})=47.1 \mathrm{~Hz}, 9 \mathrm{H}\right), 0.98(\mathrm{~d}, 3 \mathrm{H}), 1.09\left(\mathrm{~s},{ }^{3} \mathrm{~J}(\mathrm{Sn}, \mathrm{H})=\right.$ $63.7 \mathrm{~Hz}, 6 \mathrm{H}), 1.25-1.69(\mathrm{~m}, 3 \mathrm{H}), 1.85-1.90(\mathrm{~m}, 4 \mathrm{H}), 2.02\left(\mathrm{t},{ }^{3} \mathrm{~J}(\mathrm{H}, \mathrm{H})=12.6 \mathrm{~Hz}, 1 \mathrm{H}\right), 4.28(\mathrm{~s}$, $1 \mathrm{H}), 7.00-7.6(\mathrm{~m}, 5 \mathrm{H}),[\alpha]^{20}{ }_{\mathrm{D}}=-26.58^{\circ}\left(\mathrm{CHCl}_{3} ; 4.653\right)$. Anal. Calcd. for $\mathrm{C}_{19} \mathrm{H}_{32} \mathrm{OSn}: \mathrm{C}, 55.77$; H, 8.16. Found: C, 55.82; H, 8.20.

(1R,2R,5R)-(-)-5-Methyl-2-(1-methyl-1-tributylstannylethyl)-1-phenyl-1-cyclohexanol (11b). ${ }^{1} \mathrm{H}$ NMR $\left(\mathrm{CDCl}_{3}\right) \delta 0.95(\mathrm{~d}, 3 \mathrm{H}), 1.02(\mathrm{~s}, 6 \mathrm{H}), 1.20-1.33(\mathrm{~m}, 9 \mathrm{H}), 1.37\left(\mathrm{t},{ }^{3} \mathrm{~J}(\mathrm{H}, \mathrm{H})=12.4\right.$ $\mathrm{Hz}, 1 \mathrm{H}), 1.41-1.60(\mathrm{~m}, 15 \mathrm{H}), 1.75-1.84(\mathrm{~m}, 6 \mathrm{H}), 2.23-2.30(\mathrm{~m}, 2 \mathrm{H}), 2.45-2.60(\mathrm{~m}, 2 \mathrm{H}), 4.32(\mathrm{~s}$, $1 \mathrm{H}), 7.21-7.60(\mathrm{~m}, 5 \mathrm{H}),[\alpha]^{20}{ }_{\mathrm{D}}=-20.32^{\circ}\left(\mathrm{CHCl}_{3} ; 1.432\right)$.Anal. Calcd. for $\mathrm{C}_{28} \mathrm{H}_{50} \mathrm{OSn}: \mathrm{C}, 64.51$; H, 9.67. Found: C, 64.56; H, 9.72.

(1S,2R,5R)-(-)-5-Methyl-2-(1-methyl-1-tributylstannylethyl)-1-phenyl-1-cyclohexanol (12b). ${ }^{1} \mathrm{H}$ NMR $\left(\mathrm{CDCl}_{3}\right) \delta 0.91(\mathrm{~d}, 3 \mathrm{H}), 0.98(\mathrm{~s}, 6 \mathrm{H}), 1.26-1.40(\mathrm{~m}, 9 \mathrm{H}), 1.37\left(\mathrm{t},{ }^{3} \mathrm{~J}(\mathrm{H}, \mathrm{H})=12.4 \mathrm{~Hz}\right.$, $1 \mathrm{H}), 1.52-1.60(\mathrm{~m}, 15 \mathrm{H}), 1.70-1.82(\mathrm{~m}, 6 \mathrm{H}), 2.15-2.28(\mathrm{~m}, 2 \mathrm{H}), 2.36-2.41(\mathrm{~m}, 2 \mathrm{H}), 4.28(\mathrm{~s}, 1 \mathrm{H})$, 7.06-7.74 (m, $5 \mathrm{H}),[\alpha]^{20}{ }_{\mathrm{D}}=-14.02^{\circ}\left(\mathrm{CHCl}_{3} ; 2.541\right)$. Anal. Calcd. for $\mathrm{C}_{28} \mathrm{H}_{50} \mathrm{OSn}: \mathrm{C}, 64.51 ; \mathrm{H}$, 9.67. Found: C, $64.47 ; \mathrm{H}, 9.62$.

(1R,2R,5R)-(-)-5-Methyl-2-(1-methyl-1-triphenylstannylethyl)-1-phenyl-1-cyclohexanol (11c). ${ }^{1} \mathrm{H}$ NMR $\left(\mathrm{CDCl}_{3}\right) \delta 0.89(\mathrm{~d}, 3 \mathrm{H}), 1.19-1.32(\mathrm{~m}, 3 \mathrm{H}), 1.38(\mathrm{~s}, 6 \mathrm{H}), 1.54-1.68(\mathrm{~m}, 4 \mathrm{H}), 2.27$ $\left(\mathrm{t},{ }^{3} \mathrm{~J}(\mathrm{H}, \mathrm{H})=11.6 \mathrm{~Hz}, 1 \mathrm{H}\right), 4.69(\mathrm{~s}, 1 \mathrm{H}), 7.04-7.52(\mathrm{~m}, 15 \mathrm{H}), 7.54-7.76(\mathrm{~m}, 5 \mathrm{H}),[\alpha]^{20}{ }_{\mathrm{D}}=$ $40.79^{\circ}\left(\mathrm{CHCl}_{3} ; 1.662\right)$. Anal. Calcd. for $\mathrm{C}_{34} \mathrm{H}_{38} \mathrm{OSn}: \mathrm{C}, 70.26 ; \mathrm{H}, 6.59$. Found: $\mathrm{C}, 70.32 ; \mathrm{H}, 6.64$.

Reduction of ketones 6a-6c with borane in THF using (S)-3,3-diphenyl-1-methyltetrahydro$3 \mathrm{H}$-pyrrolo[1,2-c][1,3,2]oxazaborole as a catalyst

All the reactions were carried out following the same procedure. ${ }^{13}$ One experiment is described in detail to illustrate the method used. 
A stirred solution of the catalyst ( 0.1 eq., 0.146 mmoles $)$ in THF $(2.0 \mathrm{ml}$.) was slowly treated with a solution of borane in THF $(0,86 \mathrm{mmol}, 0,52 \mathrm{ml}$ of a $1.66 \mathrm{M}$ solution). After $10 \mathrm{~min}$, a solution of ketone 6a $(0.46 \mathrm{~g}, 1.45 \mathrm{mmol})$ in THF $(1.5 \mathrm{ml})$ was added slowly $(15 \mathrm{~min})$. The reaction was kept at room temperature for $20 \mathrm{~h}$. Then, the mixture was cooled to $0^{\circ} \mathrm{C}$ and $1 \mathrm{ml}$ of dry etanol was added. After this, the solution was treated with $3 \mathrm{ml}$ of $1 \mathrm{~N} \mathrm{HCl}$ and the crude product extracted in (diethyl) ether, dried with sodium sulphate, and the solvent was eliminated under reduced pressure leading to a mixture $(0.33 \mathrm{~g}, 73 \%)$ of compounds $13 \mathbf{a}$ and $14 a$. The ${ }^{119} \mathrm{Sn}-$ NMR spectrum indicated a ratio 13a $/ \mathbf{1 4 a}=82 / 18$. All the attempts to separate the mixture by vacuum distillation and column chromatography failed.

8-Trimethylstannylneomenthol (13a) and 8-trimethylstannylmenthol (14a). ${ }^{1} \mathrm{H} \mathrm{NMR}$ $\left(\mathrm{CDCl}_{3}\right.$, most significant signals from a mixture of isomers) $\delta-0.00\left(\mathrm{~s},{ }^{3} \mathrm{~J}(\mathrm{Sn}, \mathrm{H})=47.7 \mathrm{~Hz}\right)$, 0.04, (s, $\left.{ }^{3} \mathrm{~J}(\mathrm{Sn}, \mathrm{H})=48.7 \mathrm{~Hz}\right), 0.94(\mathrm{~d}, \mathrm{~J}=6.3 \mathrm{~Hz})$ ), $1.10(\mathrm{~s}), 1.28-1.52$ (m), 1.66-1.86 (m), 3.48 $\left(\mathrm{td},{ }^{3} \mathrm{~J}(\mathrm{H}, \mathrm{H})=10.2 \mathrm{~Hz}\right), 3.79\left(\mathrm{td},{ }^{3} \mathrm{~J}(\mathrm{H}, \mathrm{H})=6.5 \mathrm{~Hz}\right), 4.17(\mathrm{~s}, 1 \mathrm{H}), 4.20(\mathrm{~s}, 1 \mathrm{H}) .{ }^{13} \mathrm{C}-\mathrm{NMR}$ $\left(\mathrm{CDCl}_{3}\right.$, most significant signals from a mixture of isomers) $\delta-9.53\left({ }^{1} \mathrm{~J}(\mathrm{Sn}, \mathrm{C})=305.6 \mathrm{~Hz}\right),-9.25$ $\left({ }^{1} \mathrm{~J}(\mathrm{Sn}, \mathrm{C})=306.9 \mathrm{~Hz}\right), 21.69,22.20,22.50,23.03,24.79\left({ }^{1} \mathrm{~J}(\mathrm{Sn}, \mathrm{C})=433.6 \mathrm{~Hz}\right), 24.82\left({ }^{1} \mathrm{~J}(\mathrm{Sn}, \mathrm{C})\right.$ $=432.8 \mathrm{~Hz}), 28.40\left({ }^{3} \mathrm{~J}(\mathrm{Sn}, \mathrm{C})=12.3 \mathrm{~Hz}\right), 28.93,60.51\left({ }^{2} \mathrm{~J}(\mathrm{Sn}, \mathrm{C})=7.6 \mathrm{~Hz}\right), 61.91\left({ }^{2} \mathrm{~J}(\mathrm{Sn}, \mathrm{C})=\right.$ $6.5 \mathrm{~Hz}), 68.3\left({ }^{3} \mathrm{~J}(\mathrm{Sn}, \mathrm{C})=12.4 \mathrm{~Hz}\right), 72.4\left({ }^{3} \mathrm{~J}(\mathrm{Sn}, \mathrm{C})=12.3 \mathrm{~Hz}\right)$.

8-Tributylstannylneomenthol (13b) and 8-tributylstannylmenthol (14b). ${ }^{1} \mathrm{H} \mathrm{NMR}\left(\mathrm{CDCl}_{3}\right.$, most significant signals from a mixture of isomers) $\delta-0.81\left(\mathrm{~s},{ }^{3} \mathrm{~J}(\mathrm{Sn}, \mathrm{H})=67.5 \mathrm{~Hz}\right), 0.84,(\mathrm{~s}$, $\left.{ }^{3} \mathrm{~J}(\mathrm{Sn}, \mathrm{H})=66.5 \mathrm{~Hz}\right), 0.6-1.15(\mathrm{~m}), 1.17-1.31(\mathrm{~m}), 1.33-1.53(\mathrm{~m}), 3.37\left(\mathrm{td},{ }^{3} \mathrm{~J}(\mathrm{H}, \mathrm{H})=10.6 \mathrm{~Hz}\right)$, $3.61\left(\mathrm{td},{ }^{3} \mathrm{~J}(\mathrm{H}, \mathrm{H})=6.0 \mathrm{~Hz}\right), 4.06(\mathrm{~s}, 1 \mathrm{H}), 4.10(\mathrm{~s}, 1 \mathrm{H}) .{ }^{13} \mathrm{C}-\mathrm{NMR}\left(\mathrm{CDCl}_{3}\right.$, most significant signals from a mixture of isomers) $\delta 9.60\left({ }^{1} \mathrm{~J}(\mathrm{Sn}, \mathrm{C})=291.2 \mathrm{~Hz}\right), 9.23\left({ }^{1} \mathrm{~J}(\mathrm{Sn}, \mathrm{C})=292.3 \mathrm{~Hz}\right)$, $12.71,12.76,17.92,20.28,21.07,25.49,25.68,26.84,26.87\left({ }^{3} \mathrm{~J}(\mathrm{Sn}, \mathrm{C})=70.8 \mathrm{~Hz}\right), 30.77\left({ }^{1} \mathrm{~J}(\mathrm{Sn}\right.$, $\mathrm{C})=431.4 \mathrm{~Hz}), 30.70,60.55\left({ }^{2} \mathrm{~J}(\mathrm{Sn}, \mathrm{C})=6.5 \mathrm{~Hz}\right), 68.15\left({ }^{3} \mathrm{~J}(\mathrm{Sn}, \mathrm{C})=14.8 \mathrm{~Hz}\right), 71.24\left({ }^{3} \mathrm{~J}(\mathrm{Sn}, \mathrm{C})\right.$ $=14.1 \mathrm{~Hz})$.

8-Triphenylstannylneomenthol (13c) and 8-triphenylstannylmenthol (14c). ${ }^{1} \mathrm{H}$ NMR $\left(\mathrm{CDCl}_{3}\right.$, most significant signals from a mixture of isomers) $\delta 0.66-0.84(\mathrm{~m}), 1.13(\mathrm{t}), 1.26(\mathrm{t}, \mathrm{J}=$ $8.2 \mathrm{~Hz}), 1.34-1.61(\mathrm{~m}), 1.68(\mathrm{q}, \mathrm{J}=13.2 \mathrm{~Hz}), 3.45\left(\mathrm{td},{ }^{3} \mathrm{~J}(\mathrm{H}, \mathrm{H})=10.5 \mathrm{~Hz}\right), 3.56\left(\mathrm{td},{ }^{3} \mathrm{~J}(\mathrm{H}, \mathrm{H})=\right.$ $6.5 \mathrm{~Hz}), 4.11(\mathrm{~s}, 1 \mathrm{H}), 4.18(\mathrm{~s}, 1 \mathrm{H}), 7.12-7.37(\mathrm{~m}), 7.42-7.88(\mathrm{~m}) .{ }^{13} \mathrm{C}-\mathrm{NMR}\left(\mathrm{CDCl}_{3}\right.$, most significant signals from a mixture of isomers) $\delta, 21.42,23.10,24.40,24.53\left({ }^{3} \mathrm{~J}(\mathrm{Sn}, \mathrm{C})=16.4\right.$ $\mathrm{Hz}), 24.56\left({ }^{3} \mathrm{~J}(\mathrm{Sn}, \mathrm{C})=15.8 \mathrm{~Hz}\right), 24.79,29.65,30.98,59.85\left({ }^{2} \mathrm{~J}(\mathrm{Sn}, \mathrm{C})=7.7 \mathrm{~Hz}\right), 70.34\left({ }^{3} \mathrm{~J}(\mathrm{Sn}\right.$, $\mathrm{C})=13.5 \mathrm{~Hz}), 71.26\left({ }^{3} \mathrm{~J}(\mathrm{Sn}, \mathrm{C})=12.6 \mathrm{~Hz}\right), 136.63,136.66,136.69,136.74,141.78\left({ }^{1} \mathrm{~J}(\mathrm{Sn}, \mathrm{C})=\right.$ $360.34 \mathrm{~Hz}), 141.71\left({ }^{1} \mathrm{~J}(\mathrm{Sn}, \mathrm{C})=360.53 \mathrm{~Hz}\right), 142.82,142.85$.

\section{References}

1. Pereyre, M.; Quintard, J.P.; Rahm, A. Tin in Organic Synthesis, Butterworth: London, 1987.

2. Fleming, I.; Urch, Ch. J. J. Organomet. Chem. 1985, 285, 173.

3. (a) Wardell, J.L. Formation and cleavage of the tin-carbon bond. Harrison, P. D. In Chemistry of Tin, 1989, chapter 5, pp 145-186. Blackie, Glasgow. (b) Davies, A.G. Organotin Chemistry, VCH: Weinheim, 1997, Chapter 17. 
4. (a) Podestá, J. C.; Chopa, A. B.; Giagante, N. N.; Zúñiga, A. E. J. Organomet. Chem. 1995, 494, 5. (b) Mandolesi, S. D.; Giagante, N. N.; Dodero, V. I.; Podestá, J. C. Molecules 2000, 5, 594. Proceedings of the 12th National Symposium of Organic Chemistry (XII SINAQO), Los Cocos, Córdoba, Argentina, 14-17 November 1999.

5. (a) Doddrell, D.; Burfitt, I.; Kitching, W.; Lee, C.-H.; Mynott, R.J.; Considine, J.L.; Kuivila, H.G.; Sarma, R.H. J. Am. Chem. Soc. 1974, 96, 1640. (b) Mitchell, T.N.; Podestá, J.C.; Ayala, A. D.; Chopa, A. B. Mag. Reson. Chem. 1988, 26, 497.

6. Nakahira, H.; Ryu, I.; Ogawa, A.; Kambe, N.; Sonoda, N. Organometallics 1990, 9, 277.

7. Lecomte, V.; Stéphan, E.; Jaouen, G. Tetrahedron Lett. 2002, 43, 3463.

8. Schumann, H.; Wassermann, B. C.; J. Organomet. Chem. 1989, 365, C1.

9. Mitchell, T. N. Org. Magn. Reson. 1976, 8, 34.

10. Walton, H. M. J. Org. Chem. 1957, 22, 1161.

11. Wickham, G.; Olszowy, H.; Kitching, W. J. Org. Chem. 1982, 47, 3788.

12. Fleming, I.; Urch, Ch. J. Organomet. Chem. 1985, 285, 173.

13. Stone, G. Tetrahedron Asym. 1994, 5, 465. 